\title{
ANALISIS DINAMIK RESPON STRUKTUR GEDUNG BERATURAN DAN KETIDAKBERATURAN HORIZONTAL
}

\author{
Ummi Khoirunnissa ${ }^{1}$, Rinawati Djakfar ${ }^{2}$, Yanuar Setiawan ${ }^{3 *}$ \\ Jurusan Teknik Sipil, Politeknik Negeri Jakarta \\ Jl. Prof. Dr. G.A Siwabessy, Kampus Bary UI, Depok, 16242 \\ e-mail: ummik45@gmail.com; rinawati_djakfar@ymail.com; \\ ${ }^{*}$ Korespondensi: yanuar.setiawan@ sipil.pnj.ac.id
}

\begin{abstract}
Indonesia is a country with geographical location where 4 large tectonic plates meet. Therefore, if a collision or frictionhits the country, it is vulnerable to earthquakes. This condition makes the buildings more vulnerable to earthquakes. The effect of earthquake force and the performance of the resulting structure will be different if the same load is applied to a regular building and to an irregular building. The method to calculate the effect of the earthquake on the analysis of high-rise building structures in this study used dynamic analysis with spectrum response referred to SNI 03-1726-2012 and 2013 ETABS software program assistance (13.1.1 build 1035). This study aimed to compare the performance of the structure based on the deflection value and the story drift limits in regular and irregular buildings. In this study, the response of structural performance on three building models was calculated with variations in horizontal structure irregularity and then the results were compared. In this research, the biggest deflection was resulted on the re-entrant corner irregularity model $C$ in the $x$-direction of 7,219 $m m$ and the $y$-direction of 4,244 mm. Based on the deflection value in the $x$-direction and $y$-direction on all building models, the story drift due to the effect of the earthquake plan was less than $\Delta$ a, wherein this study obtained $\triangle a$ by $80 \mathrm{~mm}$, so it could be concluded that it was safe against the story drift limits in SNI03-1726-2012.
\end{abstract}

Keywords: spectrum response, deflection, horizontal irregularity.

\begin{abstract}
ABSTRAK
Indonesia meupakan negara dengan letak geografisnya berada di pertemuan 4 lempeng tektonik besar, dimana jika terjadi tumbukan atau gesekan rentan terjadinya gempa bumi, kondisi ini menyebabkan bangunan-bangunan tersebut lebih rentan terhadap gempa. Pengaruh gaya gempa dan kinerja struktur yang dihasilkan akan berbeda jika diaplikasikan pada gedung beraturan dengan gedung tidak beraturan untuk besaran beban yang sama. Metode untuk memperhitungkan efek gempa terhadap analisis struktur bangunan bertingkat tinggi pada penelitian ini yaitu menggunakan analisis dinamis dengan respons spektrum mengacu pada SNI 03-1726-2012 dan bantuan program software ETABS 2013 (13.1.1 build 1035). Penelitian ini bertujuan untuk membandingkan kinerja struktur dilihat dari nilai simpangan dan simpangan antar lantai izin pada gedung beraturan dan gedung tidak beraturan. Dalam penelitian ini dihitung respon kinerja struktur pada tiga model bangunan dengan variasi ketidakberaturan struktur horisontal dan kemudian dibandingkan hasilnya. Dalam penelitian ini didapatkan hasil simpangan terbesar pada gedung tidak beraturan sudut dalam model C arah-x sebesar 7,219 $\mathrm{mm}$ dan arah-y sebesar 4,244 mm. Berdasarkan nilai simpangan pada arah-x dan arah-y pada semua model bangunan, maka simpangan antar lantai akibat pengaruh gempa rencana kurang dari $\Delta a$ dimana dalam penelitian ini didapatkan $\triangle a$ sebesar $80 \mathrm{~mm}$, sehingga dapat disimpulkan aman terhadap syarat batas simpangan antar lantai izin dalam SNI-03-1726-2012.
\end{abstract}

Kata kunci: respons spektrum, simpangan, ketidakberaturan horizontal.

\section{PENDAHULUAN}

Struktur yang stabil apabila menerima beban yang sama besar, struktur tersebut akan mengalami perubahan bentuk atau berdeformasi lebih kecil dibandingkan dengan struktur yang tidak stabil [1]. Struktur bertingkat tinggi/ banyak harus dirancang mempunyai stabilitas yang memadai sesuai dengan kapasitas dan 
mampu menahan gaya lateral yang terletak pada kekakuan kolom, sehingga simpangan yang terjadi tidak melebihi syarat dari simpangan antar lantai yang diizinkan [2].

Letak Indonesia yang berada pada pertemuan empat lempeng tektonik berakibat rentan terjadinya gempa bumi. Padahal bangunan gedung pada umumnya hanya dirancang untuk menahan beban gravitasi saja dengan besar beban sama dengan massa (m) kali percepatan gravitasi (g), dengan arah vertikal kebawah [3]. Sehingga dalam perancangan struktur gedung pada seharusnya memperhitungkan juga gaya lateral (horisontal) yang diakibatkan oleh beban angin dan beban gempa [4].

Gaya lateral yang timbul akibat getaran gempa bumi akan terdistribusi pada titik berat massa bangunan disetiap lantai bangunan gedung [5]. Analisis dinamik time history merupakan metode yang paling akurat, tetapi diperlukan hitungan yang kompleks dan memakan waktu yang lama [6]. Oleh sebab itu, digunakannya analisis dinamis respon spektrum sebagai penyederhanaan dari analisis dinamik time history [7]. Konsep statik hanya memperhitungkan massa saja dan hanya cocok untuk bangunan rendah dan cenderung kaku [8] dan keakuratan terhadap analisis statik ekuivalen hanya untuk bangunan dengan maksimum tujuh lantai kebawah dengan tinggi bangunan tidak melebihi $30 \mathrm{~m}$ [9].

Konsep analisis dinamik ini memperhitungkan massa, kekakuan dan redaman [10]. Perhitungan dengan metode dinamik akan menghasilkan gaya geser dasar bangunan yang lebih kecil dari pada dengan metode statik ekuivalen [11]. Dengan intensitas yang sama akan dihasilkan kinerja struktur berbeda untuk gedung beraturan gedung tidak beraturan [12]. Penelitian ini dilakukan untuk mengetahui perbandingan kinerja struktur dari gedung beraturan dengan gedung tidak beraturan yang dapat dilihat dari nilai simpangan (deflection) [13] dan kontrol desain terhadap simpangan antar lantai tingkat izin (story drift limits) [14]. Dimana batasan simpangan antar lantai tingkat desain $(\Delta)$, yaitu tidak boleh melebihi simpangan antar lantai tingkat $\operatorname{izin}(\Delta \mathrm{a})[15]$.

Bangunan tahan gempa didesain dengan tujuan untuk menghindari terjadinya kegagalan struktur dan kehilangan korban jiwa, dengan tiga kriteria standar sebagai berikut: a) Pada gempa kecil tidak diperbolehkan terjadi kerusakan sama sekali. b) Kerusakan arsitektural diperbolehkan terjadi ketika terjadi gempa sedang tetapi bukan merupakan kerusakan struktural. c) Pada gempa kuat diperbolehkan terjadinya kerusakan struktural dan non-struktural pada tetapi kerusakan yang terjadi tidak sampai menyebabkan runtuhnya bangunan [16]. Banyaknya korban jiwa dapat disebabkan oleh mudah runtuhnya bangunan akibat mutu bangunan yang sangat rapuh [17].

Pada penelitian terdahulu yang dilakukan oleh Hotma L. Purba et. al (2014) ditinjau dari simpangan struktur semakin besar proyeksi sudut dalam maka akan semakin besar simpangan yang terjadi dengan proyeksi sudut dalam 50\% arah-x dan $60 \%$ arah-y dengan selisih $+32,57 \%$ dan $+8,13 \%$ [7].

\section{METODE PENELITIAN}

Studi Literatur.

Studi literatur dilakukan dengan menelaah literatur dari jurnal-jurnal, buku, peraturan/ pedoman yang terkait dengan penelitian ini. Antara lain SNI 1727-1989 [18] dan SNI 1727-2013 untuk menentukan pembebanan gedung baik beban mati maupun beban hidup serta menentukan beban hujan dan beban angin [19], SNI 1726-2012 sebagai acuan dalam mendesain respon spektrum, E-book Aplikasi ETABS Pada Perancangan Gedung 15 
Lantai Dengan Struktur Beton Bertulang Menggunakan Sistem Ganda (Dual System) Sebagai Penahan Beban Gempa Sesuai Standard Code SNI 1726 : 2012 sebagai referensi menggunakan software ETABS [20] dan jurnal - jurnal yang berkaitan dengan analisis respon spektrum, serta jurnal - jurnal lain penelitian sebelumnya.

Penelitian dimulai dengan menghitung respon spektrum berdasarkan lokasi dan data tanah. Diagram alir pembuatan respon spektrum disajikan pada Gambar 1. Pada tahap berikutnya dilakukan analisis kinerja struktur dengan diagram alir seperti Gambar 2.

Pada penelitian ini akan membandingkan respon struktur yaitu simpangan dan simpangan antar lantai dari ketiga model bangunan. Denah gedung dapat dilihat pada Gambar 35.

Data Struktur.

Data struktur Hotel baik untuk gedung beraturan dan gedung dengan ketidakberaturan horisontal adalah sebagai berikut :

1. Fungsi Gedung : Gedung Hotel.

2. Lokasi : Lengkong Gudang, Serpong, Tangerang Selatan, Banten 15321

3. Luas Bangunan : $\pm 14.848 \mathrm{~m}^{2} /$ lantai. Terdiri dari 8 lantai meliputi, 1 lantai Lobby, 7 lantai Hotel. Elevasi lantai dapat dilihat pada Tabel 1.
Tabel 1. Elevasi Lantai Hotel

\begin{tabular}{lc}
\hline Lantai & Elevasi $(\mathbf{m})$ \\
\hline Base & 0,00 \\
Lantai 1 & $+4,00$ \\
Lantai 2 & $+8,00$ \\
Lantai 3 & $+12,00$ \\
Lantai 4 & $+16,00$ \\
Lantai 5 & $+20,00$ \\
Lantai 6 & $+24,00$ \\
Lantai 7 & $+28,00$ \\
Lantai 8 & $+32,00$ \\
\hline
\end{tabular}

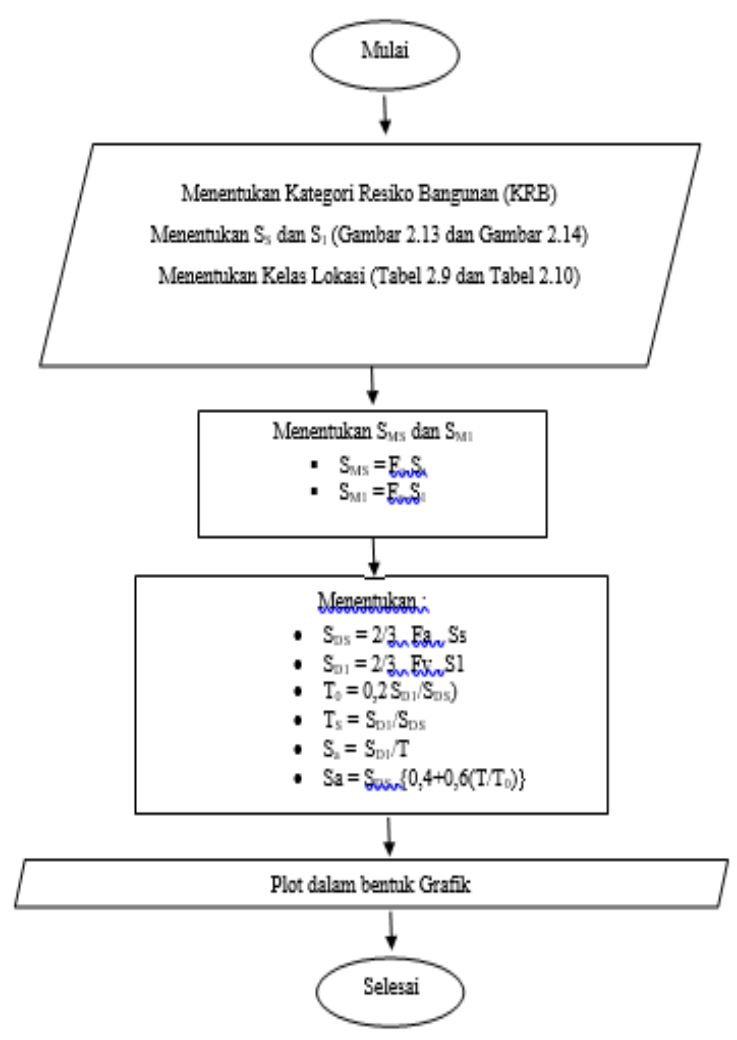

Gambar 1. Diagram Alir Pembuatan Grafik Respons Spektrum 


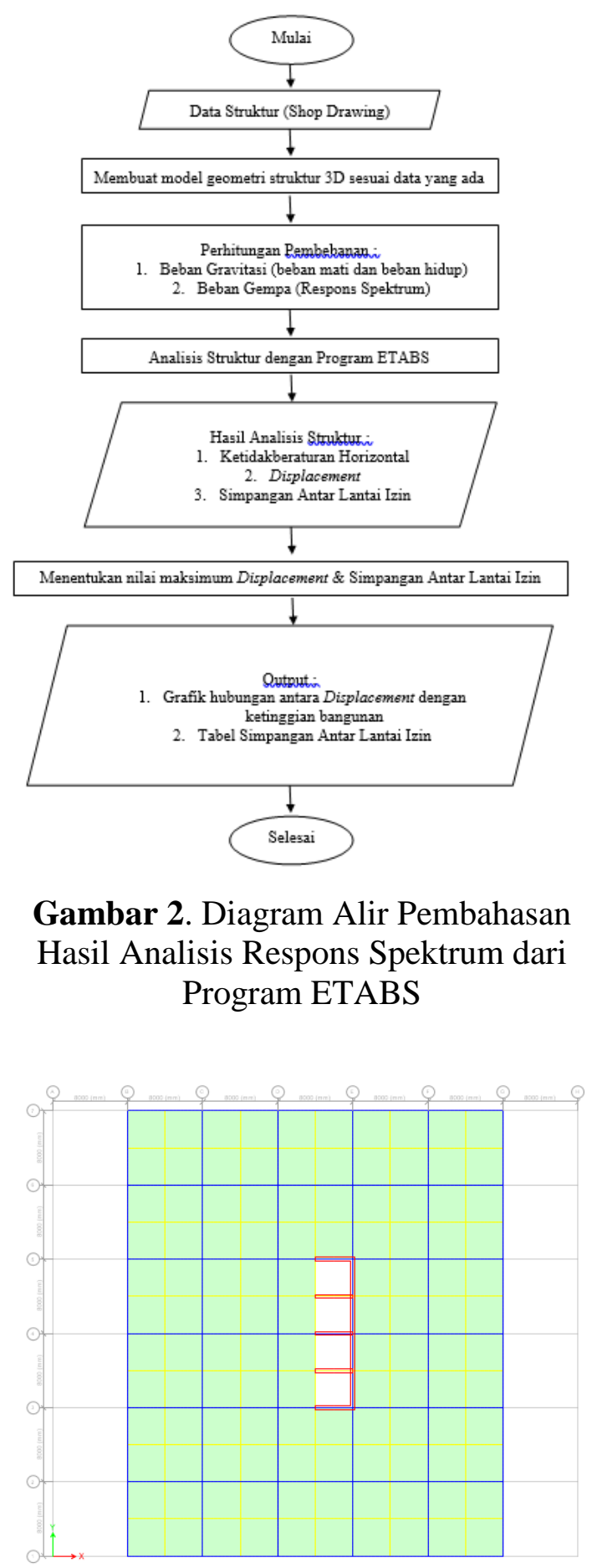

Gambar 3. Denah gedung beraturan model A

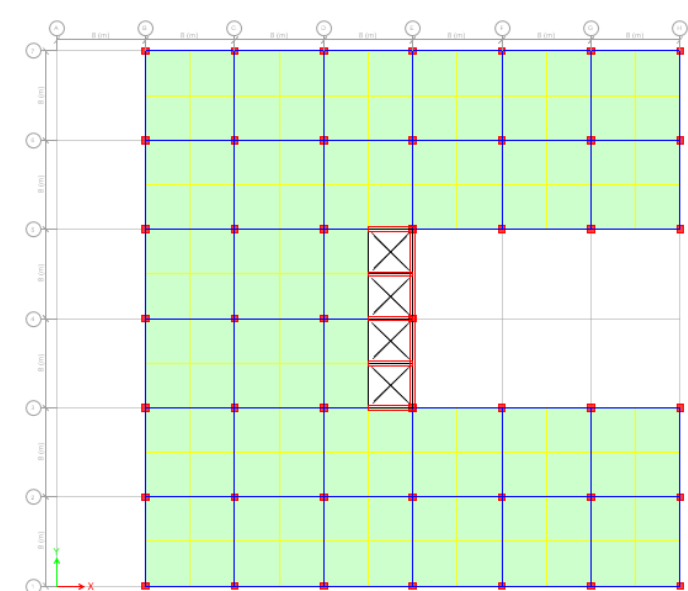

Gambar 4. Denah gedung tidakberaturan model B

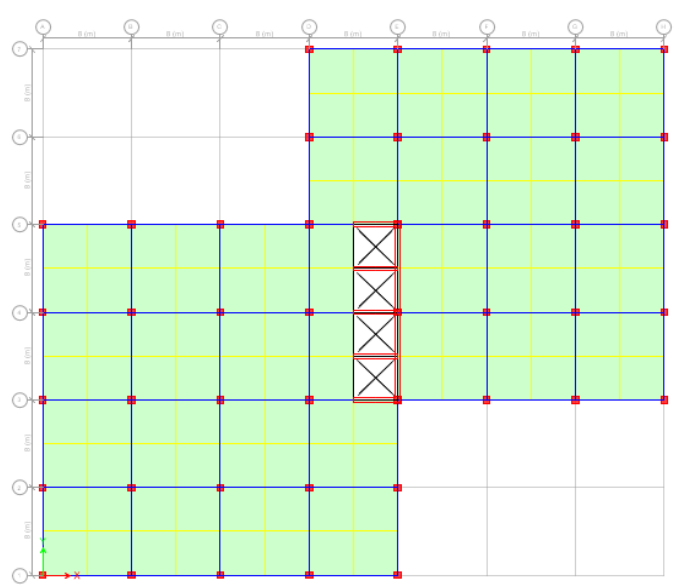

Gambar 5. Denah gedung tidakberaturan model $\mathrm{C}$

4. Dimensi Struktur :
a. Pelat lantai : $15 \mathrm{~cm}$, mutu beton Fc' $30 \mathrm{MPa}$
b. Pelat atap : $15 \mathrm{~cm}$, mutu beton Fc' $30 \mathrm{MPa}$
c. Shear wall : $40 \mathrm{~cm}$, mutu beton Fc' $42 \mathrm{MPa}$
d. Balok Tipe dan dimensi balok dapat dilihat pada Tabel 2.

Tabel 2. Tipe-tipe Balok

\begin{tabular}{clc}
\hline No & Tipe Balok & Dimensi (mm) \\
\hline 1 & Balok Induk & B1 $400 \times 500$ \\
2 & Balok Anak & BA $300 \times 400$ \\
\hline e. & Kolom \\
& Tipe dan dimensi kolom dapat \\
& dilihat pada Tabel 3.
\end{tabular}


Tabel 3. Tipe-tipe Kolom

\begin{tabular}{cccc}
\hline \multirow{2}{*}{ No } & Kode & \multicolumn{2}{c}{ Dimensi } \\
\cline { 3 - 4 } & $\begin{array}{c}\text { Panjang } \\
(\mathbf{m m})\end{array}$ & $\begin{array}{c}\text { Lebar } \\
(\mathbf{m m})\end{array}$ \\
\hline 1 & $\mathrm{~K} 1$ & 600 & 600 \\
\hline
\end{tabular}

Guna menganalisis struktur gedung ini digunakan metode analisis dinamis respon spektrum sesuai dengan tata cara perencanaan ketahanan gempa untuk struktur banguna gedung dan non gedung dalam SNI-03-1726-2012. Dalam menganalisis hasil perhitungan struktur dibantu dengan menggunakan software ETABS 2013 (13.1.1 build 1035). Kemudian akan dilakukan pembandingan hasil analisa berupa besaran nilai simpangan (deflection) dan dilakukan kontrol desain terhadap simpangan yang terjadi.

\section{HASIL dan PEMBAHASAN}

Ketidakberaturan.

Berdasarkan pada SNI 03-1726-2012 bahwa ketidakberturan sudut dalam terjadi apabila memenuhi syarat: Py > 0,15Ly dan Px > 0,15 Lx. Perhitungan ketidakberaturan sudut dalam tersajikan pada Tabel 4.

Tabel 4. Perhitungan Ketidakberaturan Sudut Dalam

\begin{tabular}{|c|c|c|c|c|c|c|c|}
\hline \multirow[t]{2}{*}{ No } & ฮ & 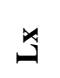 & 3 & $a$ & $\vec{B}$ & $\tilde{Z}$ & $\stackrel{\bar{z}}{z}$ \\
\hline & 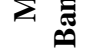 & (m) & (m) & (m) & (m) & $(\%)$ & $(\%)$ \\
\hline 1 & $\begin{array}{l}\ll \\
0 \\
ٌ \\
:\end{array}$ & 40 & 48 & 0 & 0 & 0 & 0 \\
\hline 2 & $\stackrel{\infty}{\mathscr{\Xi}}$ & 48 & 48 & 24 & 16 & 43 & 33 \\
\hline 3 & 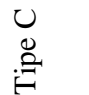 & 56 & 48 & 24 & 16 & 50 & 33 \\
\hline
\end{tabular}

Berdasarkan perhitungan

ketidakberaturan sudut dalam, didapatkan hasil bahwa gedung model A merupakan bangunan beraturan. Sedangkan gedung model B memiliki ketidakberaturan sudut dalam sebesar $43 \%$ arah-x dan 33\% arah-y, serta untuk gedung model $\mathrm{C}$ memiliki ketidakberaturan sudut dalam sebesar $50 \%$ arah-x dan 33\% arah-y.

Simpangan (Deflection).

Besar perbandingan nilai simpangan yang didapatkan dari hasil analisis dinamik respon spektrum dari ketiga model bangunan disajikan dalam bentuk tabel dan gambar dalam satuan meter pada Tabel 5-6 dan Gambar 6-7.

Tabel 5. Selisih Perbedaan Simpangan

\begin{tabular}{cccccc}
\multicolumn{3}{c}{ Arah X } \\
\hline & $\begin{array}{c}\text { Model } \\
\text { A }\end{array}$ & \multicolumn{2}{c}{ Model B } & \multicolumn{2}{c}{ Model C } \\
\cline { 2 - 6 } & & & & \\
\hline 1 & 0,352 & 0,45 & 28,6 & 0,533 & 51,4 \\
2 & 2,235 & 2,57 & 15 & 2,77 & 23,8 \\
3 & 2,800 & 3,400 & 21,4 & 4,10 & 46,4 \\
4 & 4,452 & 4,720 & 6,02 & 4,88 & 9,61 \\
5 & 5,560 & 5,734 & 3,12 & 5,85 & 5,23 \\
6 & 5,615 & 5,912 & 5,28 & 5,99 & 6,66 \\
7 & 5,970 & 6,534 & 9,45 & 6,58 & 10,3 \\
8 & 6,355 & 6,861 & 7,96 & 7,439 & 17,1
\end{tabular}

Tabel 6. Selisih Perbedaan Simpangan Arah Y

\begin{tabular}{|c|c|c|c|c|c|}
\hline \multirow[b]{2}{*}{ 胥 } & \multirow{2}{*}{ 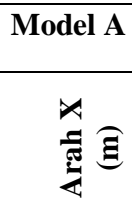 } & \multicolumn{2}{|c|}{ Model B } & \multicolumn{2}{|c|}{ Model C } \\
\hline & & $\frac{x}{\pi}$ & 㺼 & 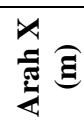 & 昰 \\
\hline 1 & 0,217 & 0,321 & 47,7 & 0,372 & 71,1 \\
\hline 2 & 0,781 & 0,855 & 9,46 & 0,995 & 27,4 \\
\hline 3 & 1,311 & 1,483 & 13,1 & 1,718 & 31 \\
\hline 4 & 1,642 & 1,741 & 6,03 & 2,455 & 49,5 \\
\hline 5 & 2,173 & 2,434 & 12,01 & 3,110 & 43,1 \\
\hline 6 & 2,471 & 2,804 & 13,5 & 3,481 & 40,9 \\
\hline 7 & 3,207 & 3,302 & 2,96 & 3,946 & 23 \\
\hline 8 & 3,422 & 3,840 & 12,2 & 4,540 & 32,7 \\
\hline
\end{tabular}




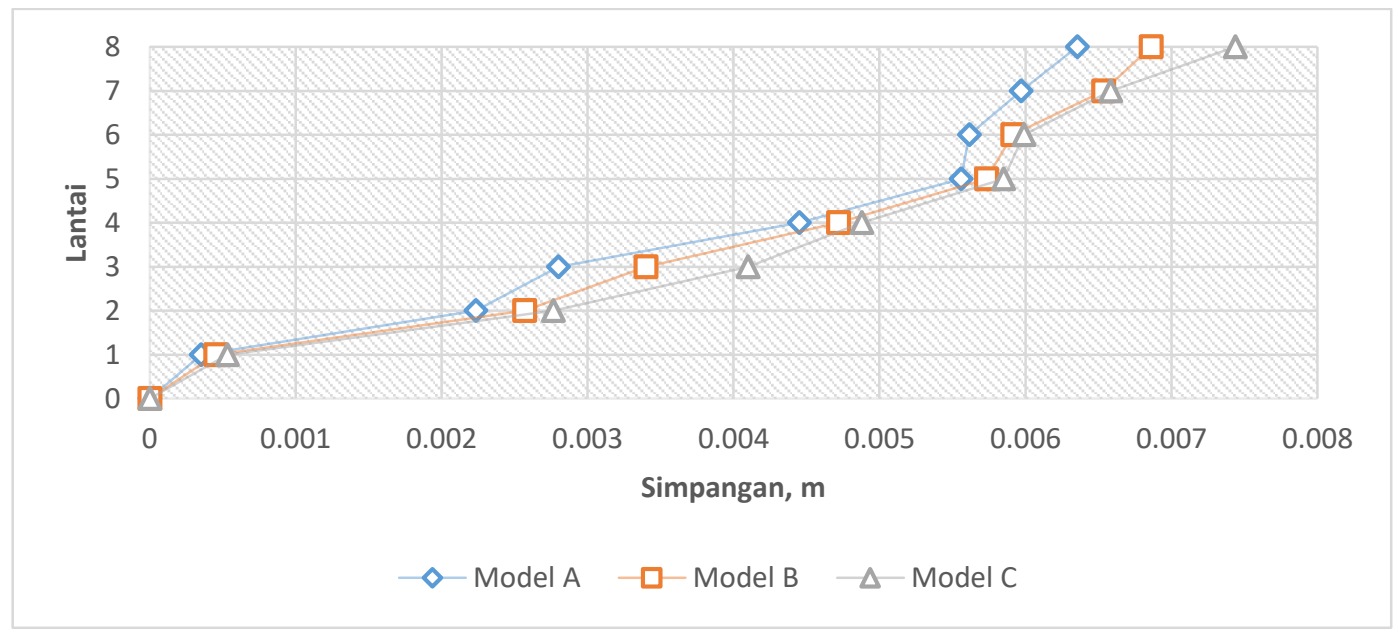

Gambar 6. Simpangan Arah X

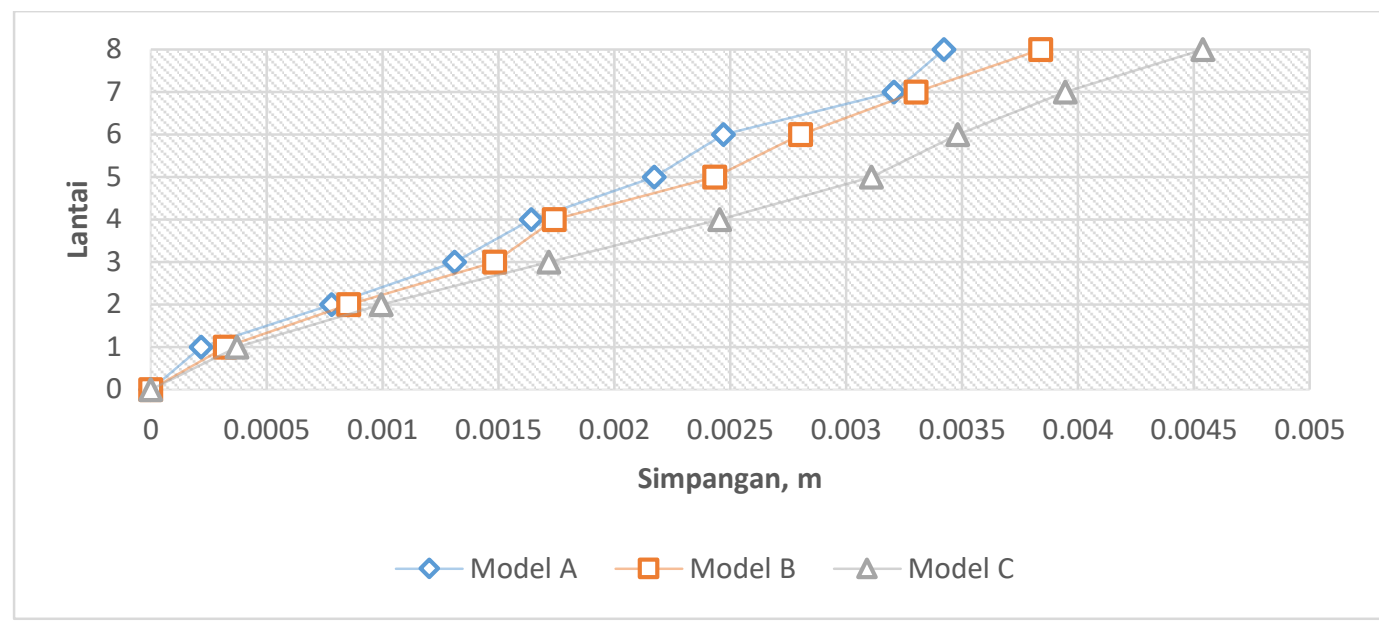

Gambar 7. Simpangan Arah Y

Berdasarkan data hasil analisis yang telah tersaji pada Tabel 5-6 serta Gambar 6-7 didapat bahwa model bangunan yang memiliki simpangan (deflection) terbesar untuk arah $\mathrm{x}$ maupun arah y adalah model bangunan $\mathrm{C}$ dengan ketidakberaturan sudut dalam arah x sebesar 50\% dan arah y sebesar $33 \%$. Dengan nilai simpangan (deflection) arah $\mathrm{x}$ sebesar 0,00744 m dan untuk nilai simpangan (deflection) arah y sebesar 0,00454 m. Hal ini sesuai dengan hasil penelitian Hotma L. Purba et. al (2014) ditinjau dari simpangan struktur semakin besar proyeksi sudut dalam maka akan semakin besar simpangan yang terjadi [7].

Simpangan Antar Lantai Izin.

Kontrol desain struktur perlu dilakukan pengecekan terhadap batas simpangan antar lantai tingkat desain $(\Delta)$ dan tidak boleh melebihi simpangan antar lantai tingkat izin $(\Delta \mathrm{a})$. Berdasarkan nilai simpangan (deflection) maksimum yang telah disajikan pada Tabel 7-12.

Tabel 7. Simpangan Antar Lantai Izin Arah X Model A 
Ummi, dkk., Analisis Dinamik Respon...

\begin{tabular}{|c|c|c|c|c|c|c|}
\hline 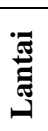 & $\begin{array}{c}\mathbf{h} \\
(\mathbf{m m})\end{array}$ & $\begin{array}{c}\boldsymbol{\delta} \mathbf{e} \\
(\mathbf{m m})\end{array}$ & $\begin{array}{c}\boldsymbol{\delta} \\
(\mathbf{m m})\end{array}$ & $\begin{array}{c}\Delta \\
(\mathbf{m m})\end{array}$ & $\begin{array}{c}\Delta \mathbf{a} \\
(\mathbf{m m})\end{array}$ & Ket \\
\hline 8 & 4000 & 6,355 & 34,954 & 2,119 & 80 & OK \\
\hline 7 & 4000 & 5,97 & 32,835 & 1,953 & 80 & OK \\
\hline 6 & 4000 & 5,615 & 30,883 & 0,303 & 80 & OK \\
\hline 5 & 4000 & 5,56 & 30,58 & 6,094 & 80 & OK \\
\hline 4 & 4000 & 4,452 & 24,486 & 9,086 & 80 & OK \\
\hline 3 & 4000 & 2,8 & 15,4 & 3,108 & 80 & OK \\
\hline 2 & 4000 & 2,235 & 12,293 & 10,357 & 80 & OK \\
\hline 1 & 4000 & 0,352 & 1,936 & 1,936 & 80 & OK \\
\hline
\end{tabular}

Tabel 8. Simpangan Antar Lantai Izin Arah X Model B

\begin{tabular}{|c|c|c|c|c|c|c|}
\hline 莡 & $\begin{array}{c}\mathbf{h} \\
(\mathbf{m m})\end{array}$ & $\begin{array}{c}\boldsymbol{\delta} \mathbf{e} \\
(\mathbf{m m})\end{array}$ & $\begin{array}{c}\boldsymbol{\delta} \\
(\mathbf{m m})\end{array}$ & $\begin{array}{c}\Delta \\
(\mathbf{m m})\end{array}$ & $\begin{array}{c}\Delta \mathbf{a} \\
(\mathbf{m m})\end{array}$ & Ket \\
\hline 8 & 4000 & 6,861 & 37,736 & 1,799 & 80 & OK \\
\hline 7 & 4000 & 6,534 & 35,937 & 3,424 & 80 & OK \\
\hline 6 & 4000 & 5,912 & 32,513 & 0,979 & 80 & OK \\
\hline 5 & 4000 & 5,734 & 31,534 & 5,574 & 80 & OK \\
\hline 4 & 4000 & 4,72 & 25,96 & 7,26 & 80 & OK \\
\hline 3 & 4000 & 3,4 & 18,7 & 4,565 & 80 & OK \\
\hline 2 & 4000 & 2,57 & 14,135 & 11,644 & 80 & OK \\
\hline 1 & 4000 & 0,453 & 2,492 & 2,492 & 80 & OK \\
\hline
\end{tabular}

Tabel 9. Simpangan Antar Lantai Izin Arah X Model C

\begin{tabular}{|c|c|c|c|c|c|c|}
\hline 莡 & $\begin{array}{c}\text { h } \\
(\mathbf{m m})\end{array}$ & $\begin{array}{c}\boldsymbol{\delta} \mathbf{e} \\
(\mathbf{m m})\end{array}$ & $\begin{array}{c}\boldsymbol{\delta} \\
(\mathbf{m m})\end{array}$ & $\begin{array}{c}\Delta \\
(\mathbf{m m})\end{array}$ & $\begin{array}{c}\Delta \mathbf{a} \\
(\mathbf{m m})\end{array}$ & Ket \\
\hline 8 & 4000 & 7,439 & 40,915 & 4,708 & 80 & OK \\
\hline 7 & 4000 & 6,583 & 36,207 & 3,267 & 80 & OK \\
\hline 6 & 4000 & 5,989 & 32,94 & 0,759 & 80 & OK \\
\hline 5 & 4000 & 5,851 & 32,18 & 5,341 & 80 & OK \\
\hline 4 & 4000 & 4,88 & 26,84 & 4,29 & 80 & OK \\
\hline 3 & 4000 & 4,1 & 22,55 & 7,337 & 80 & OK \\
\hline 2 & 4000 & 2,766 & 15,213 & 12,282 & 80 & OK \\
\hline 1 & 4000 & 0,533 & 2,9315 & 2,932 & 80 & $\mathrm{OK}$ \\
\hline
\end{tabular}

Tabel 10. Simpangan Antar Lantai Izin Arah Y Model A

\begin{tabular}{|c|c|c|c|c|c|c|}
\hline 莡 & $\begin{array}{c}\mathbf{h} \\
(\mathbf{m m})\end{array}$ & $\begin{array}{c}\boldsymbol{\delta} \mathbf{e} \\
(\mathbf{m m})\end{array}$ & $\begin{array}{c}\boldsymbol{\delta} \\
(\mathbf{m m})\end{array}$ & $\begin{array}{c}\Delta \\
(\mathbf{m m})\end{array}$ & $\begin{array}{c}\Delta \mathbf{a} \\
(\mathbf{m m})\end{array}$ & Ket \\
\hline 8 & 4000 & 3,411 & 18,758 & 2,120 & 80 & OK \\
\hline 7 & 4000 & 3,025 & 16,638 & 2,811 & 80 & OK \\
\hline 6 & 4000 & 2,514 & 13,827 & 3,130 & 80 & OK \\
\hline 5 & 4000 & 1,945 & 10,698 & 2,206 & 80 & OK \\
\hline 4 & 4000 & 1,544 & 8,492 & 2,591 & 80 & OK \\
\hline 3 & 4000 & 1,073 & 5,902 & 1,826 & 80 & OK \\
\hline 2 & 4000 & 0,741 & 4,076 & 3,285 & 80 & OK \\
\hline 1 & 4000 & 0,144 & 0,791 & 0,791 & 80 & OK \\
\hline
\end{tabular}

Tabel 11. Simpangan Antar Lantai Izin Arah Y Model B

\begin{tabular}{|c|c|c|c|c|c|c|}
\hline 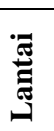 & $\begin{array}{c}\mathbf{h} \\
(\mathbf{m m})\end{array}$ & $\begin{array}{c}\boldsymbol{\delta} \mathbf{e} \\
(\mathbf{m m})\end{array}$ & $\begin{array}{c}\boldsymbol{\delta} \\
(\mathbf{m m})\end{array}$ & $\begin{array}{c}\Delta \\
(\mathbf{m m})\end{array}$ & $\begin{array}{c}\Delta \mathbf{a} \\
(\mathbf{m m})\end{array}$ & Ket \\
\hline 8 & 4000 & 3,544 & 19,492 & 2,431 & 80 & OK \\
\hline 7 & 4000 & 3,102 & 17,061 & 2,739 & 80 & OK \\
\hline 6 & 4000 & 2,604 & 14,322 & 2,668 & 80 & OK \\
\hline 5 & 4000 & 2,119 & 11,655 & 2,767 & 80 & OK \\
\hline 4 & 4000 & 1,616 & 8,888 & 2,596 & 80 & OK \\
\hline 3 & 4000 & 1,144 & 6,292 & 1,771 & 80 & OK \\
\hline 2 & 4000 & 0,822 & 4,521 & 3,531 & 80 & OK \\
\hline 1 & 4000 & 0,180 & 0,990 & 0,990 & 80 & OK \\
\hline
\end{tabular}


Tabel 12. Simpangan Antar Lantai Izin

\begin{tabular}{ccccccc}
\multicolumn{7}{c}{ Arah Y Model C } \\
\hline \multirow{2}{*}{ Lantai } & $\mathbf{h}$ & $\boldsymbol{\delta} \mathbf{e}$ & $\boldsymbol{\delta}$ & $\boldsymbol{\Delta}$ & $\boldsymbol{\Delta a}$ & Ket \\
& $(\mathbf{m m})$ & $(\mathbf{m m})$ & $(\mathbf{m m})$ & $(\mathbf{m m})$ & $(\mathbf{m m})$ & \\
\hline 8 & 4000 & 4,244 & 23,342 & 1,590 & 80 & OK \\
7 & 4000 & 3,955 & 21,753 & 2,607 & 80 & OK \\
6 & 4000 & 3,481 & 19,146 & 2,712 & 80 & OK \\
5 & 4000 & 2,988 & 16,434 & 3,493 & 80 & OK \\
4 & 4000 & 2,353 & 12,942 & 3,696 & 80 & OK \\
3 & 4000 & 1,681 & 9,246 & 3,817 & 80 & OK \\
2 & 4000 & 0,987 & 5,429 & 3,691 & 80 & OK \\
1 & 4000 & 0,316 & 1,738 & 1,738 & 80 & OK \\
\hline
\end{tabular}

Sesuai dengan perhitungan simpangan antar lantai tingkat untuk arah-x maupun arah-y yang telah disajikan pada Tabel 7-12 didapatkan bahwa simpangan antar tingkat yang terjadi pada ketiga model bangunan masih memenuhi standar yaitu dibawah nilai simpangan yang diizinkan sesuai dengan perhitungan dalam SNI 03-1726-2012 yaitu kurang dari $\Delta \mathrm{a}$ sebesar $80 \mathrm{~mm}$.

\section{KESIMPULAN}

Ditinjau dari simpangan (deflection) pada struktur, gedung beraturan model A mengalami simpangan maksimum sebesar 6,355 mm arah-x dan 3,422 mm arah-y. Gedung tidak beraturan sudut dalam model B yaitu gedung dengan proyeksi sudut dalam $43 \%$ arah-x dan $33 \%$ arah-y mengalami simpangan maksimum sebesar 6,861 mm arah-x dan $3,84 \mathrm{~mm}$ arah-y dengan selisih $+7,96 \%$ arah-x dan 12,22\% arah-y jika dibandingkan dengan gedung beraturan model A. Gedung tidak beraturan sudut dalam model $\mathrm{C}$ yaitu gedung dengan proyeksi sudut dalam $50 \%$ arah-x dan $33 \%$ arah-y mengalami simpangan maksimum sebesar 7,439 mm arah-x dan 4,54 mm arah-y dengan selisih $+17,05 \%$ arah-x dan $32,67 \%$ arah-y jika dibandingkan dengan gedung beraturan model A.

Berdasarkan hasil analisa tersebut didapatkan bahwa semakin besar proyeksi sudut dalam pada suatu bangunan maka akan semakin besar simpangan yang terjadi pada bangunan tersebut. Simpangan antar lantai izin yang terjadi baik pada gedung beraturan model A, gedung tidak beraturan model B yaitu gedung dengan proyeksi sudut dalam $43 \%$ arah-x dan 33\% arah-y dan gedung tidak beraturan model $\mathrm{C}$ yaitu gedung dengan proyeksi sudut dalam $50 \%$ arah-x dan 33\% arah-y, ketiganya masih memenuhi standar yaitu dibawah nilai simpangan yang diizinkan sesuai dengan perhitungan dalam SNI 03-17262012 yaitu kurang dari $\Delta$ a sebesar 80 $\mathrm{mm}$.

Pada penelitian ini memiliki keterbatasan waktu dengan melihat hasil penelitian ini, direkomendasikan bahwa dapat menambah metode analisis yang digunakan untuk mendapatkan hasil perbandingan yang mendekati ideal. Misalnya antara metode analisis dinamik respon spektrum dengan metode analisis dinamik time history.

\section{DAFTAR PUSTAKA}

[1] Schodek, Daniel L. 1999. Struktur Edisi kedua. Erlangga. Jakarta.

[2] Hariyanto, Agus. 2011. Skripsi: Analisis Kinerja Struktur pada Bangunan Bertingkat Tidak Beraturan dengan Analisis Dinamik Respon Spektrum. Universitas Sebelas Maret. Surakarta.

[3] IITI-BMTCP. (TT). What are The Seismic Effects on Structures. Earthquake Tip-5. Indian Institute of Technology Kanpur. India.

[4] Sunarto, Amira. 2018. Skripsi: Perbandingan Respon Struktur 
Gedung Tidak beraturan Horizontal Akibat Gempa dengan Analisis Statik dan Dinamik. UII Press. Yogyakarta.

[5] Faizah, Restu. 2015. "Studi Perbandingan Pembebanan Gempa Statik Ekuivalen dan Dinamik Time History pada Gedung Bertingkat di Yogyakarta," Jurnal Ilmiah Semesta Teknika vol.18, no.2, 190-199.

[6] Prawirodikromo, W. 2012. Seismologi Teknik dan Rekayasa Kegempaan, Pustaka Pelajar. Yogyakarta.

[7] Purba, Hotma L. 2014. "Analisis Kinerja Struktur pada Bangunan Bertingkat Beraturan dan Ketidakberaturan Horizontal sesuai SNI 03-1726-2012," Jurnal Teknik Sipil dan Lingkungan vol.2, no.4, 710-717.

[8] Widodo. 2001. Respon Dinamik Struktur Elastik. UII Press. Yogyakarta.

[9] Tarigan, M. dan Teruna. D. R. 2014. "Perbandingan Respon Struktur Beraturan dan Ketidakberaturan Horizontal Sudut dalam Akibat Gempa Dengan Menggunakan Analisis Statik Ekuivalen dan Time History," Jurnal Teknik Sipil USU vo. 3 , no.1, 1-10.

[10] Tumilar, S. 2011. Prosedur Analisis Struktur Beton Akibat Gempa Menurut SNI-03-17262010. Seminar HAKI 28 Juli 2011. Jakarta.

[11] Kusumastuti. 2010. Pengaruh Tinggi Struktur dan Jumlah Bentang Terhadap Kontribusi Mode Pada Struktur Beton Bertulang Bertingkat Banyak dengan Pendekatan Kekakuan
Kolom Shear Building dan Cara Muto. Tesis Magister Teknik Sipil UII. Yogyakarta.

[12] Iskandarsyah, H. 2009. Analisis Respon Spektrum pada Bangunan yang Menggunakan Yielding Damper Akibat Gaya Gempa. Departemen Teknik Sipil Fakultaas Teknik Universitas Sumatera Utara. Medan.

[13] Wantalangie, R. O., Pangouw, J. D., \& Windah, R. S. 2016. "Analisa Statik Dan Dinamik Gedung Bertingkat Banyak Akibat Gempa Berdasarkan SNI 17262012 Dengan Variasi Jumlah Tingkat," Jurnal Sipil Statik vol.4, no.8, 471-480.

[14] Hasan A, Astira I F. 2013. "Analisis perbandingan simpangan lateral bangunan tinggi dengan variasi bentuk dan posisi dinding geser studi kasus: proyek apartemen the Royale Springhill Residences." Jurnal Teknik Sipil dan Lingkungan Vol. 1, no.1,4756.

[15] Badan Standarisasi Nasional. 2012. Standar Perencanaan Ketahanan Gempa Untuk Struktur Bangunan Gedung. BSN, Jakarta.

[16] Uniform Building Code. 1997. Structural Engineering Design Provisions, Volume 2, ICBO, U.S.A.

[17] Prasetya, Tiar. 2006. Gempa Bumi: Ciri dan Cara Menanggulanginya, Gitanagiri, Yogyakarta.

[18] Badan Standarisasi Nasional. 1989. Pedoman Perencanaan Pembebanan untuk Rumah dan Gedung. BSN, Jakarta.

[19] Badan Standarisasi Nasional. 2013. Beban Minimum untuk 
Ummi, dkk., Analisis Dinamik Respon...

Perancangan Bangunan Gedung dan Struktur Lain. BSN, Jakarta.

[20] Hamzah F. M. 2015. E-book Aplikasi Etabs Pada Perancangan Gedung 15 Lantai Dengan
Struktur Beton Bertulang Menggunakan Sistem Ganda (Dual System) Sebagai Penahan Beban Gempa Sesuai Standard Code SNI 1726: 2012. Jakarta 